\title{
ROBERT HENRY PFEIFFER
}

\author{
Born at Bologna, Italy, February 14, 1892
}

Died at Cambridge, Massachusetts, March 16, 1958

Professor Pfeiffer died in the thirty-seventh year of his teaching in the Harvard University. His contribution to the Review began in the first year of his teaching ("An Unknown Source of Luther's Theology," XV, 1922, 297-299), and includes one of his searching studies in biblical law ("Transmission of the Book of the Covenant," XXIII, 1931, 99-109). In the last years of his teaching he has served as a member of the editorial board.

The range of Professor Pfeiffer's energy and interests marks him as one of the last in a grand succession of Orientalists who moved freely among the disciplines of Assyriology, Near Eastern archaeology, and Old Testament literature. For twenty-seven years he served as curator of the Semitic Museum; his principal editions of four volumes of Assyrian texts are permanent contributions to Oriental research, though little known by non-specialists; through his standard handbooks, Introduction to the Old Testament and History of New Testament Times, he has transmitted to a new generation the best of a rich tradition of biblical scholarship.

His colleagues of the Harvard Divinity School and of the Review gratefully acknowledge our debt to his learning and to his work in our academic community. He has left with us also the impress of his person. In him were united in a peculiar way, gentleness and courage, warmth and objectivity, simplicity and wisdom. 